University of Montana

ScholarWorks at University of Montana

\title{
$9-2013$
}

\section{Bacterial Endophytes Enhance Competition by Invasive Plants}

\author{
Marnie E. Rout \\ University of Montana - Missoula \\ Thomas H. Chrzanowski \\ University of Texas at Arlington \\ Tara K. Westlie \\ University of Montana \\ Thomas H. DeLuca \\ Ragan M. Callaway \\ University of Montana - Missoula \\ See next page for additional authors
}

Follow this and additional works at: https://scholarworks.umt.edu/biosci_pubs

Part of the Biology Commons

Let us know how access to this document benefits you.

\section{Recommended Citation}

Rout, Marnie E.; Chrzanowski, Thomas H.; Westlie, Tara K.; DeLuca, Thomas H.; Callaway, Ragan M.; and Holben, William E., "Bacterial Endophytes Enhance Competition by Invasive Plants" (2013). Biological Sciences Faculty Publications. 18.

https://scholarworks.umt.edu/biosci_pubs/18

This Article is brought to you for free and open access by the Biological Sciences at ScholarWorks at University of Montana. It has been accepted for inclusion in Biological Sciences Faculty Publications by an authorized administrator of ScholarWorks at University of Montana. For more information, please contact scholarworks@mso.umt.edu. 


\section{Authors}

Marnie E. Rout, Thomas H. Chrzanowski, Tara K. Westlie, Thomas H. DeLuca, Ragan M. Callaway, and William E. Holben 


\title{
Botany
}

American Journal of Botany 100(9): 1726-1737. 2013.

\section{SPECIAL INVITED PAPER-RHIZOSPHERE INTERACTIONS}

\section{BACTERIAL ENDOPHYTES ENHANCE COMPETITION BY INVASIVE PLANTS ${ }^{1}$}

\author{
Marnie E. Rout ${ }^{2,3,6}$, Thomas H. Chrzanowski ${ }^{4}$, Tara K. Westlie ${ }^{2}$, Thomas H. DeLuca ${ }^{5}$, \\ Ragan M. Callaway ${ }^{2}$, and William E. Holben ${ }^{2,3}$
}

${ }^{2}$ Division of Biological Sciences, The University of Montana, Missoula, Montana 59812, USA; ${ }^{3}$ Montana Ecology of Infectious Diseases, The University of Montana, Missoula, Montana 59812, USA; ${ }^{4}$ Department of Biology, The University of Texas

Arlington, Arlington, Texas 76019, USA; and ${ }^{5}$ School of Environmental and Forest Sciences, University of Washington, Seattle, Washington 98195, USA

- Premise of the study: Invasive plants can alter soil microbial communities and profoundly alter ecosystem processes. In the invasive grass Sorghum halepense, these disruptions are consequences of rhizome-associated bacterial endophytes. We describe the effects of $\mathrm{N}_{2}$-fixing bacterial strains from S. halepense (Rout and Chrzanowski, 2009) on plant growth and show that bacteria interact with the plant to alter soil nutrient cycles, enabling persistence of the invasive.

- Methods: We assessed fluxes in soil nutrients for $\sim 4 \mathrm{yr}$ across a site invaded by $S$. halepense. We assayed the $\mathrm{N}_{2}$-fixing bacteria in vitro for phosphate solubilization, iron chelation, and production of the plant-growth hormone indole-3-acetic acid (IAA). We assessed the plant's ability to recruit bacterial partners from substrates and vertically transmit endophytes to seeds and used an antibiotic approach to inhibit bacterial activity in planta and assess microbial contributions to plant growth.

- Key results: We found persistent alterations to eight biogeochemical cycles (including nitrogen, phosphorus, and iron) in soils invaded by $S$. halepense. In this context, three bacterial isolates solubilized phosphate, and all produced iron siderophores and IAA in vitro. In growth chamber experiments, bacteria were transmitted vertically, and molecular analysis of bacterial community fingerprints from rhizomes indicated that endophytes are also horizontally recruited. Inhibiting bacterial activity with antibiotics resulted in significant declines in plant growth rate and biomass, with pronounced rhizome reductions.

- Conclusions: This work suggests a major role of endophytes on growth and resource allocation of an invasive plant. Indeed, bacterial isolate physiology is correlated with invader effects on biogeochemical cycles of nitrogen, phosphate, and iron.

Key words: bacterial endophytes; biogeochemical cycles; Gramineae; indole-3-acetic acid; iron chelation; microbially enhanced competitiveness; plant invasions; phosphate solubilization; Sorghum halepense.

Invasive plants can suppress or eliminate native species (Vilà and Weiner, 2004; Maron and Marler, 2008; Inderjit et al., 2011) and profoundly alter ecosystem functions (Vitousek et al., 1997; Gordon, 1998; Ehrenfeld, 2003, Liao et al., 2008; Rout and Callaway, 2009, 2012). In a meta-analysis, Liao et al. (2008) reported that invaded ecosystems were characterized by increased concentrations of carbon $(\mathrm{C})$ and nitrogen $(\mathrm{N})$ in plant tissues and increased concentrations of various forms of $\mathrm{N}$ in soils. Others have reported that invaded ecosystems also have increased pools of various forms of soil phosphorus (P) (Ehrenfeld, 2003;

\footnotetext{
${ }^{1}$ Manuscript received 1 November 2012; revision accepted 15 April 2013.

Author contributions: M.E.R. designed the research; M.E.R., T.K.W., and T.H.C. performed the research; W.E.H., T.H.C., and T.H.D. contributed new reagents/analytical tools; M.E.R., T.K.W., and R.M.C. analyzed data; and M.E.R., R.M.C., and W.E.H. wrote the paper. The authors thank J. Pollock for providing assistance with all of the microbial physiology assays during this project. M.E.R. was supported by The University of Montana, and Montana-Ecology of Infectious Diseases NSF-IGERT program under grant No. 0504628.

${ }^{6}$ Author for correspondence (e-mail: marnie.rout@mso.umt.edu; marnie. rout@unthsc.edu); University of North Texas Health Science Center, Department of Forensics and Investigative Genetics, 3500 Camp Bowie Blvd., Fort Worth, TX 76107 USA; phone: (817) 735-5039
}

doi:10.3732/ajb.1200577
Allison and Vitousek, 2004; Thorpe et al., 2006). Alterations of nutrient cycles, especially those associated with the $\mathrm{N}$ cycle, are particularity interesting since bioavailable $\mathrm{N}$ is frequently limiting in terrestrial ecosystems and changes to ecosystem $\mathrm{N}$ pools may thus impact community structure across multiple trophic levels. The combined increase in soil $\mathrm{N}$ and $\mathrm{P}$ pools associated with invaded ecosystems may explain one of the "paradoxes" often associated with plant invasions: an increase in net primary productivity (NPP) despite a decrease in plant diversity (Liao et al., 2008; Rout and Callaway, 2009, 2012).

Native and exotic plant species that form mutualisms with $\mathrm{N}_{2}$-fixing bacteria increase soil $\mathrm{N}$ concentrations (Stevenson and Cole, 1999). Transformations within the soil $\mathrm{N}$ cycle are also driven by microbiota; thus, changes in soil $\mathrm{N}$ pools within invaded ecosystems are likely caused by major changes in plantmicrobe or plant-soil-microbe interactions (Rout and Callaway, 2009). Previous research shows that the invasive grass Sorghum halepense (L.) Pers. (Poaceae) harbors $\mathrm{N}_{2}$-fixing bacteria in its rhizomes and rhizosphere and that soils invaded by this grass contained higher concentrations of available N, P, alkaline metals, and several micronutrients compared to native soils (Rout and Chrzanowski, 2009). Specific characteristics of the leaf tissues of $S$. halepense may contribute to rates of litter decomposition, hence nutrient cycling, since the leaves contain a constitutive defense compound (dhurrin) that is an $\mathrm{N}$-containing cyanogenic glycoside. However, the endophytic bacterial symbionts might 
also affect biogeochemical cycling through other physiological functions in addition to $\mathrm{N}_{2}$ fixation. For example, some bacteria categorized as plant growth-promoting bacteria also solubilize $\mathrm{P}$ (Rodríguez and Fraga, 1999) or can liberate iron (Fe) into bioavailable forms, while others produce various plant-growth hormones (Patten and Glick, 1996; Glick, 1995; Hardoim et al., 2008).

Here we report several years of data on altered soil biogeochemical nutrient pools occurring with $S$. halepense invasion and assess several aspects of $S$. halepense-bacterial mutualisms related to plant invasion and ecosystem impacts. Based on earlier findings in this system, we hypothesized that invaded soil nutrient pools would have higher concentrations of available N, P, and alkaline metals compared with native soils. In addition, we measured aspects of the in vitro metabolism of five bacterial endophytes isolated by Rout and Chrzanowski (2009) to assess their potential to drive changes in soil biogeochemistry. The effects of these bacterial endophytes on $S$. halepense growth and biomass were also quantified. We tested the hypotheses that $S$. halepense could acquire bacterial endophytes through horizontal recruitment from soils and that bacteria could be vertically transmitted to the seeds.

\section{MATERIALS AND METHODS}

Site description and soil nutrient analyses - The $\sim 12$ ha study site is located in North Central Texas at the convergence of Fort Worth Prairie and Western Crosstimbers inside the Fort Worth Nature Center and Refuge (FWNCR) $\left(32^{\circ} 84^{\prime} \mathrm{N}, 97^{\circ} 47^{\prime} \mathrm{W}, \sim 200 \mathrm{~m}\right.$ a.s.l.). The site is a remnant tallgrass prairie, where the dominant native grass is Schizachyrium scoparium (little bluestem) with the grasses Bouteloua curtipendula (sideoats grama), Sporobolus compositus (tall dropseed), Bouteloua hirsuta (hairy grama), Sorghastrum nutans (indiangrass), and Andropogon gerardii (big bluestem) as minor components (Rout et al., 2013). This site has undergone extensive invasion by $S$. halepense over the last 25 yr (Rout and Chrzanowski, 2009; Rout et al., 2013). The plant has encroached upon native prairie at $\sim 0.45 \mathrm{~m} \cdot \mathrm{yr}^{-1}$ (Rout et al., 2013) along a broad linear front, indicating expansion primarily via rhizomatous growth. The site is now characterized by three plant communities-noninvaded, hereafter native prairie; moderately invaded (i.e., at the invasion front), hereafter transition prairie; and heavily invaded, hereafter invaded prairie.

Nutrient analyses were conducted on soils using methods described by Rout and Chrzanowski (2009) from the same $1-\mathrm{m}^{2}$ plots used in that study. Briefly, soil cores (three to five discrete, $60 \mathrm{cc}$ volumes) were collected quarterly throughout each year from permanent $1-\mathrm{m}^{2}$ plots inside each prairie community (native, transition, invaded; $n=4, N=12$ ). Cores from each plot were pooled into a composite sample, air-dried, homogenized, and plant debris removed. Soil samples were collected quarterly November 2006 through July 2010, using methods and commercial analyses previously documented (Rout and Chrzanowski, 2009).

Bacterial strains and in vitro bacterial analyses-The five bacterial strains isolated from rhizomes of $S$. halepense were most closely related to the following taxa based on near full-length 16S rRNA gene homology and the RDPII classification module (http://rdp.cme.msu.edu/classifier/): Agrobacterium tumefaciens, Caulobacter vibroides ATCC strain 16262T, Pseudomonas jessenii strain CIP 105274, Sphingobium amiense strain YT, and Xanthomonas melonis strain LMG8670 (for detailed sequence analyses, see Rout and Chrzanowski, 2009). To assess effects of these endophytes on soil biochemical parameters and via what mechanisms, we performed a suite of biochemical and physiological tests, including metabolic functions related to $\mathrm{P}$ solubilization and Fe chelation (iron siderophore production), and production of plant-growth-promoting substances (indole-3-acetic acid).

Phosphate solubility by endophytes in vitro-Phosphate solubility was determined using modified methods of Nautiyal (1999). Briefly, bacteria were grown in yeast extract phosphate salts broth (YP, see Fiske and Subbarow, 1925) at room temperature with shaking (180 rpm, model 4230, New Brunswick Scientific, Enfield, Connecticut, USA) to an $\mathrm{OD}_{600}$ of 0.5 , then $20 \mu \mathrm{L}$ of each strain was individually inoculated (in triplicate) into $125 \mathrm{~mL}$ Erlenmeyer flasks containing $20 \mathrm{~mL}$ of National Botanical Research Institute's phosphate growth medium without yeast extract (NBRIP, Nautiyal, 1999). Cultures were incubated for $2 \mathrm{~d}$ at $30^{\circ} \mathrm{C}$ with shaking, then cells were pelleted by centrifugation $(13000 \times g$ for $10 \mathrm{~min}$ at $4^{\circ} \mathrm{C}$ ). Soluble reactive phosphorus (SRP) in $10 \mathrm{~mL}$ of the supernatant was measured with a spectrophotometer (model UV-1601, Shimadzu, Columbia, Maryland, USA) after Fiske and Subbarow (1925). Uninoculated sterile NBRIP medium served as a negative control and blank.

Iron siderophore production by endophytes in vitro-Glassware was carefully rinsed with $6 \mathrm{~mol} / \mathrm{L} \mathrm{HCl}$, then rinsed with sterile high resistance water $(3 \times)$ prior to use. Trace iron was removed from the medium (deferration) by gently stirring for $1 \mathrm{~h}$ with Chelex 100 resin $\left(5 \mathrm{~g} 100 \cdot \mathrm{mL}^{-1}\right.$, BioRad, Hercules, California, USA). Resin was subsequently removed by filtration $(0.22 \mu \mathrm{m}$ acetate filter), and medium was dispensed into acid-washed growth flasks, sterilized by autoclaving. We used an adaptation of the universal chrome azurol S (CAS) liquid assay (Schwyn and Neilands, 1987), which is an overlay-based modification, the O-CAS method, reportedly more sensitive than the liquid CAS approach (Pérez-Miranda et al., 2007). The overlay agar contained CAS $60.5 \mathrm{mg}$, hexadecyltrimetyl ammonium bromide (HDTMA) $72.9 \mathrm{mg}$, piperazine-1,4-bis(2-ethanesulfonic acid) (PIPES) $30.24 \mathrm{~g}$, and $1 \mathrm{mmol} / \mathrm{L} \mathrm{FeCl}_{3} \cdot 6 \mathrm{H} 2 \mathrm{O}$ in $10 \mathrm{~mL}$ of $10 \mathrm{mmol} / \mathrm{L} \mathrm{HCl}$ and agarose $(0.9 \%$, w/v) as gelling agent. The overlay $(10 \mathrm{~mL})$ was applied over bacterial colonies that had been growing for $3 \mathrm{~d}$ at $30^{\circ} \mathrm{C}$ on deferrated yeast-peptone (YP) agar containing (per liter) $10 \mathrm{~g}$ yeast, $20 \mathrm{~g}$ peptone, and $15 \mathrm{~g}$ agar. Plates were incubated for an additional $24 \mathrm{~h}$ once the CAS overlay was applied. Siderophore production was assessed and considered positive when color developed in the agar overlay. Assays were done in triplicate, and individual isolates placed on nondeferrated medium served as negative controls.

Indole-3-acetic acid (IAA) production by endophytes in vitro-Bacterial production of IAA was determined by the colorimetric analysis developed by Sarwar and Kremer (1995) and modified by Grube et al. (2009). IAA growth medium was used to assess the ability of the bacterial isolates to utilize tryptophan, a precursor to IAA, as the sole $\mathrm{N}$ source and contained (per liter) $5.0 \mathrm{~g}$ dextrose, $0.025 \mathrm{~g}$ yeast, and $0.204 \mathrm{~g}$ L-tryptophan. IAA medium was inoculated with a 1:250 dilution of bacterial cultures previously grown at $30^{\circ} \mathrm{C}$ in $\mathrm{YP}$ broth, which contained (per liter) $10 \mathrm{~g}$ yeast and $20 \mathrm{~g}$ peptone, to an $\mathrm{OD}_{600}$ of 0.5 with shaking. The IAA cultures were subsequently incubated with shaking for $3 \mathrm{~d}$ in the dark at room temperature. Cells were pelleted by centrifugation (as above) and a sample of supernatant was collected for quantifying IAA production. The sample was mixed with Salkowski reagent $(50.0 \mathrm{mmol} / \mathrm{L}$ $\mathrm{FeCl}_{3} \cdot 6 \mathrm{H}_{2} \mathrm{O}$ in $35 \% \mathrm{v} / \mathrm{v} \mathrm{HClO}_{4}$ ) at a ratio of $3: 2$ and incubated for $30 \mathrm{~min}$ in the dark, then IAA concentration was determined based on optical density at $530 \mathrm{~nm}$ (Hewlett Packard Instruments/Agilent, model 1100, Santa Clara, California, USA). Assays were conducted in triplicate, and uninoculated sterile IAA medium served as negative controls and blanks.

Data are reported as the mean concentration $( \pm \mathrm{SD})$ after $48 \mathrm{~h}(\mathrm{SRP})$ or $72 \mathrm{~h}$ (IAA) incubations; values for negative controls were subtracted from values for the experimental samples. Iron siderophore production was determined qualitatively by visual examination of plates after $24 \mathrm{~h}$ of growth.

Plant-associated analyses-Seeds from 20 populations of S. halepense were collected from the states of Arizona, Louisiana, Mississippi, Oklahoma, and Texas in June 2007 and stored at $4^{\circ} \mathrm{C}$ before use. Randomly selected seeds from these 20 populations were pooled for each experiment.

Seed surface sterilization - Seeds were surface-sterilized by soaking in sterile high resistance water for $5 \mathrm{~min}$, followed by sequential submersion in $1 \%$ chloramine- $\mathrm{T}$ detergent solution $(5 \mathrm{~min}), 95 \%$ ethanol ( $1 \mathrm{~min})$, then $1.6 \%$ hypochlorite $(5 \mathrm{~min}$ ), with rinsing $3 \times$ with sterile high resistance water between each step. Surface sterilization efficacy was assessed by randomly selecting 15 seeds and streaking them (without tearing open the seed coat) across the surface of several standard microbiological media agar plates. Plates were prepared in triplicate and incubated at $37^{\circ} \mathrm{C}$ for $\sim 2 \mathrm{wk}$ to reveal the presence of bacterial or fungal contaminants. Six media were used: JNF agar (Baldani et al., 1996), R2 agar (Reasoner et al., 1979), minimal agar, nutrient agar, mycobiotic agar, and potato dextrose agar (Atlas, 2004).

Experimental design to assess endophyte acquisition (horizontal recruitment) and potential for (vertical) transmission-For determining whether plants were able to acquire bacterial endophytes from their surrounding environment 
(i.e., horizontal acquisition), surface-sterilized seeds were germinated in sterile glass Petri dishes ( $90 \mathrm{~mm}$ diameter) on sterile Whatman \#1 filter paper moistened with $2 \mathrm{~mL}$ of sterile high resistance water. Dishes (20 seeds per dish) were sealed with parafilm and incubated in the dark at room temperature. After germination (7 d), seedlings were aseptically transferred into thrice-autoclaved (on separate days) silica sand in autoclave-sterilized plastic cups $(\sim 946 \mathrm{~mL}, \sim 9 \mathrm{~cm}$ diameter). Replicate cups, planted with one seed each, received one of three microbial slurry amendments that were based on soil slurries generated from $S$. halepense-invaded prairie soil obtained from the field site. The microbial slurry amendments (10:1 sterile high resistance water to sieved soil, thoroughly mixed) were as follows: soil slurry filtered through a $1.0 \mu \mathrm{m}$ pore filter (Whatman, GE Healthcare, Piscataway, New Jersey) to remove the fungal component and other large particles, leaving indigenous bacteria in the slurry, hereafter invaded-soil bacterial slurry (ISBS); soil slurry filtered through a $0.22 \mu \mathrm{m}$ pore filter (Whatman, GE Healthcare, Piscataway, New Jersey,) to remove fungi and indigenous bacteria, then supplemented with the five previously isolated, $\mathrm{N}_{2}$-fixing bacteria associated with $S$. halepense, hereafter, Sorghum $\mathrm{N}_{2}$-fixing slurry $\left(\mathrm{SN}_{2} \mathrm{FS}\right)$; or soil slurry filtered through a $0.22 \mu \mathrm{m}$ pore filter with no further amendment, hereafter, sterile soil slurry (SSS). Bacterial concentrations in slurries from the ISBS and $\mathrm{SN}_{2} \mathrm{FS}$ treatments were determined by $4^{\prime}, 6$ diamidino-2-phenylindole (DAPI, Sigma, St. Louis, Missouri) staining microscopic enumeration using standard techniques and ranged $10^{6}-10^{8} \mathrm{cells} \cdot \mathrm{mL}^{-1}$. ISBS, $\mathrm{SN}_{2} \mathrm{FS}$, and SSS were applied twice weekly during seedling growth $(21 \mathrm{~d})$ at a volume of $250 \mathrm{~mL}$ at each application. Plants were watered weekly for the remainder of the study ( $69 \mathrm{~d}$ ) with filter-sterilized liquid fertilizer (per $1 \mathrm{~L}$ from $1 \mathrm{~mol} / \mathrm{L}$ stock solutions: $2 \mathrm{~mL}$ micronutrients; $2 \mathrm{~mL}$ Fe-EDTA; $2 \mathrm{~mL} \mathrm{MgSO}_{4}$; $\left.1 \mathrm{~mL} \mathrm{KH}_{2} \mathrm{PO}_{4}\right)$ supplemented with nitrogen $\left(1000 \mathrm{mg} \mathrm{NO}{ }_{3}-\mathrm{N} \cdot \mathrm{L}^{-1}\right)$ in the form of $\mathrm{KNO}_{3}$ and $\mathrm{Ca}\left(\mathrm{NO}_{3}\right)_{2}$, or a nitrogen-free salt-solution $\left(0 \mathrm{mg} \mathrm{N} \cdot \mathrm{L}^{-1}\right)$ as $\mathrm{KCl}$ and $\mathrm{CaCl}_{2}$. Experimental treatments consisted of three microbial slurry amendments (ISBS, $\left.\mathrm{SN}_{2} \mathrm{FS}, \mathrm{SSS}\right)$ and two fertilizers $(+\mathrm{N},-\mathrm{N} ; n=30, N=180)$.

Determining horizontal recruitment of bacterial endophytes from rhizomes-16S rRNA gene-based denaturing gel gradient electrophoresis (16SDGGE) was used to compare the bacterial community signatures associated with a subset of plants in the microbial soil-slurry treatments $(n=6, N=36)$ and assess whether they were capable of recruiting bacteria from the physical substrates. Rhizomes $(0.25-0.75 \mathrm{~g})$ were harvested and surface sterilized (as described above), outer surfaces were then removed (see Rout and Chrzanowski, 2009) and the remaining tissue ground in $1 \mathrm{~mL}$ of sterile phosphate-buffered saline ( $\mathrm{pH} 7$ ) using a sterile mortar and pestle. Bacterial genomic DNA was extracted from ground rhizome tissue, in duplicate, using the Ultra Clean Microbial DNA Isolation Kit (MoBio, Carlsbad, California, USA). Amplicons $(\sim 371 \mathrm{bp})$ of the 16S rRNA gene of bacteria present in the tissue were amplified using the generally conserved primer pair 536f and 907r (Feris et al., 2003). Amplicons from the duplicate extraction of each rhizome sample were pooled, then analyzed in triplicate by DGGE to generate plant-associated bacterial community fingerprints for each rhizome sample. Triplicates were tested for similarity using pattern-matching software before being compiled into one representative fingerprint per sample for comparative analyses between treatments (see Statistical analyses below).

Detecting vertical transmission via nitrogenase activity from rhizomes-A subset of plants in the microbial soil-slurry treatments $(n=9, N=54)$ was used to measure nitrogenase activity using the acetylene reduction (AR) assay as described by Rout and Chrzanowski (2009). Briefly, rhizomes (0.25-0.75 g wet mass) were harvested, surface sterilized (as above), and assayed for AR rates (Shimadzu GC-2014 Columbia, Maryland, USA). Controls (in triplicate per treatment) consisted of tubes containing rhizomes without acetylene to account for endogenous ethylene production.

Experimental design to assess impacts of endogenous endophytes on plant growth - Surface-sterilized seeds were germinated under sterile conditions as described above. After germination (7 d), seedlings were aseptically transferred into tissue-culture grade Magenta boxes $(250 \mathrm{~mL}$ volume; Fisher Scientific, Hampton, New Hampshire, USA) filled with $200 \mathrm{~mL}$ of antibiotic-amended sterile Rout's agar hydroponic (RAH) medium, a semisolid inert agar with $5 \mathrm{~g} \cdot \mathrm{L}^{-1}$ of Difco Noble agar (Becton-Dickenson, Sparks, Maryland, USA) and $12 \mathrm{~mL}$ of filter-sterilized $(0.22 \mu \mathrm{m}$ pore $)$ liquid fertilizer supplemented with either high $\mathrm{N}$ or devoid of $\mathrm{N}$ (as described above). Thus, Magenta boxes were filled with RAH medium and supplemented with $\mathrm{N}(+\mathrm{N} ; n=20)$ or devoid of $\mathrm{N}(-\mathrm{N}$; $n=20$ ). The lids of the Magenta boxes were modified with a 1-cm-diameter hole to accommodate seedlings and covered in aluminum foil to exclude light. Individual seedlings planted in the RAH media were established for $17 \mathrm{~d}$, when half in each fertilizer treatment $(n=10)$ received $1 \mathrm{~mL}$ of tetracycline $(12.5$ $\mathrm{mg} \cdot \mathrm{mL}^{-1}$ ) injected into the RAH medium in the proximity of the visibly apparent roots; the remaining half were injected with an equal volume of sterile water (controls). Tetracycline, a broad-spectrum bacteriostatic antibiotic effectively inhibited growth of the bacterial isolates used in this study without conferring antibiotic resistance (data not shown) and was added to the medium at this minimal inhibitory concentration. A second antibiotic treatment was administered $32 \mathrm{~d}$ post planting. Each seedling was grown for $60 \mathrm{~d}$ post planting. Experimental treatments consisted of two fertilizers (described above) $(+\mathrm{N} ;-\mathrm{N})$ and seed-sown plants that either harbored any putative endophytes (E) in an active state (EA), or in a tetracycline-inhibited state (EI), resulting in four treatments with 10 replicates each $(E A+N$; EA-N; EI+N; and EI-N). This suite of treatments allowed us to determine whether there was any effect of inhibiting putative endophytes on plant growth, measured as height and biomass (detailed below) in N-rich and N-lacking substrates.

Growth-chamber conditions and plant measurements-Plants in all treatments were incubated in a growth chamber at $22^{\circ}-26^{\circ} \mathrm{C}$ and $65-70 \%$ relative humidity on a $12 \mathrm{~h} \mathrm{light/12} \mathrm{h}$ dark cycle. Individual plant heights were measured daily throughout the study until harvest. At harvest, a subset of plants in the microbial slurry amendments to assess horizontal recruitment and vertical transmission $(n=15, N=90)$ and all plants in the sterile RAH medium/tetracycline treatments to assess impacts of endogenous endophytes on plant growth $(n=10, N=40)$ were dried $\left(3 \mathrm{~d}, 60^{\circ} \mathrm{C}\right)$, and total mass, separated by tissue type (above- and belowground biomass), was recorded.

Statistical analyses and abbreviations - Soil biogeochemistry data and all plant measures (growth, biomass, AR rates) were analyzed separately with repeated measures multivariate or univariate analyses of variance (ANOVA), as appropriate. For soils, main effects of soil source (native, transition, and invaded prairie) and time (month) were used in the model. Main effects of microbial slurry amendments (ISBS, $\mathrm{SN}_{2} \mathrm{FS}, \mathrm{SSS}$ ), fertilizer $(+\mathrm{N},-\mathrm{N})$, and time (day) were used in ANOVA assessing horizontal recruitment and vertical transmission. When assessing impacts of endogenous endophytes on plant growth, main effects of endophyte activity state (active, inactive) and fertilizer $(+\mathrm{N},-\mathrm{N})$ were used. Normality and homogeneity of variances were examined and data were transformed as necessary when appropriate. Kruskal-Wallis ANOVA on ranks was applied when data failed normality or equal variance tests. Post hoc means comparisons were conducted using Tukey's honestly significant differences (HSD) (ANOVA) or Dunn's method (Kruskal-Wallis). DGGE pattern matching analysis was performed using BioNumerics v4.6 software (Applied Maths, Kortjik, Belgium). Since visual examination of gel patterns is subjective and prone to human bias, digital images of DGGE gels were captured and analyzed using the pattern matching algorithms supplied with the software. Detrended correspondence analysis (DCA, PC-ORD v6 MjM, Gleneden Beach, Oregon, USA) was used to analyze DGGE banding patterns. All other statistical analyses were conducted using SPSS v19 software (IBM, Somers, New York, USA). Data are reported as means and standard errors. Several nonstandard abbreviations are used in this work; to aid in following these, Table 1 lists the abbreviations and their meanings referenced in the Methods, Results, and figures.

\section{RESULTS}

Soil nutrient analyses-Soils invaded by $S$. halepense had higher concentrations of most nutrients $\left(\mathrm{Cu}^{2+}, \mathrm{Fe}^{3+}, \mathrm{Mg}^{2+}, \mathrm{Mn}^{2+}\right.$, $\mathrm{Zn}^{2+}, \mathrm{NO}_{3}{ }^{-}-\mathrm{N}, \mathrm{PO}_{4}{ }^{3-}-\mathrm{P}$, and $\mathrm{K}^{+}$) throughout the study compared to transition area and native prairie soils (Figs. 1, 2; Appendix 1). The exception to these increases was calcium (Ca), which was 18.2 and $21.2 \%$ lower in invaded soils than in transition and native soils, respectively. This decrease was associated with community type (native, transition, or invaded; $F_{2,34}=19.405$, $P<0.0001$ ) but not time (seasonality; $F_{2,34}=1.615, \mathrm{~ns}$ ). Native soils were alkaline $(\mathrm{pH}=7.54 \pm 0.03)$, transition soils near neutral $(\mathrm{pH}=7.14 \pm 0.09)$ and invaded soils acidic $(\mathrm{pH}=6.91 \pm$ $0.04)$. The $\mathrm{pH}$ differences confirmed community types $\left(F_{2,34}=\right.$ $26.084, P<0.0001$ ), but was not influenced by time (seasonality, $F_{2,34}=1.535$, ns). All soil chemistries with the exception of copper $\left(\mathrm{Cu}^{2+}\right)$ had greater $F$ values due to the effect of community 
TABLE 1. Nonstandard abbreviations referenced in this work.

\begin{tabular}{ll}
\hline \hline Abbreviation & \multicolumn{1}{c}{ Definition } \\
\hline RAH medium & Rout's agar hydroponic growth medium \\
$\mathrm{SRP}$ & $\begin{array}{c}\text { Soluble reactive phosphate } \\
\text { Acetylene reduction rates determined by acetylene } \\
\text { reduction assay } \\
\text { Endophyte active }\end{array}$ \\
$\mathrm{EA}$ & Endophyte inactive (via tetracycline addition) \\
$\mathrm{EI}$ & Nitrogen fertilization addition \\
$\mathrm{+N}$ & Nitrogen fertilization deprivation \\
$-\mathrm{N}$ & Invaded soil bacteria slurry \\
Microbial slurry amendments \\
$\mathrm{ISBS}$ & Sorghum $\mathrm{N}_{2}$-fixing bacteria slurry \\
$\mathrm{SN} \mathrm{N}_{2} \mathrm{FS}$ & Sterile soil slurry (via $0.22 \mu \mathrm{m}$ filtration) \\
$\mathrm{SSS}$ &
\end{tabular}

type than for time, indicating that the effect of $S$. halepense on soil biogeochemistry was stronger than that of season (Figs. 1, 2; Appendix 1). All variables assayed showed seasonal fluxes, and data collected in the fall of 2007 showed a downward trend in all nutrients with exception of $\mathrm{pH}$. The pattern of high concentrations of $\mathrm{Cu}^{2+}, \mathrm{Fe}^{3+}, \mathrm{Mg}^{2+}, \mathrm{Mn}^{2+}, \mathrm{Zn}^{2+}, \mathrm{NO}_{3}{ }^{-}-\mathrm{N}, \mathrm{PO}_{4}{ }^{3-}-\mathrm{P}$, and $\mathrm{K}^{+}$, low concentrations of $\mathrm{Ca}$, and lower $\mathrm{pH}$ in invaded soils compared to native soils remained consistent throughout the study period.

In-vitro bacterial physiology analyses-Phosphate solubilization by endophytes in vitro-The NBRIP medium contained insoluble $\mathrm{Ca}_{3}\left(\mathrm{PO}_{4}\right)_{2}$ as the only source of phosphorus. All five bacterial isolates grew well in this medium, producing visibly turbid cultures with distinct cell pellets upon centrifugation, indicating that all were capable of mobilizing insoluble phosphorus. However, three of the five strains (P.jessenii, S. amiense, and $X$. melonis) mobilized phosphorus in excess of that required for growth and liberated SRP into the medium (Table 2).

Iron siderophore production by endophytes in vitro-Iron siderophores are low molecular weight molecules often characterized as hydroxamates or catechols (Rodríguez and Fraga, 1999). Both types of siderophores can be detected by the O-CAS assay (see Methods). The production of yellow to yellow-orange pigment is indicative of the presence of hydroxamates, whereas orange to red pigments are indicative of catechols (Schwyn and Neilands, 1987; Pérez-Miranda et al., 2007). The O-CAS assay indicated that each of the five isolates produced hydroxamates and that $S$. amiense also produced catechols (Table 2).

IAA production by endophytes in vitro-Each of the five bacterial isolates produced measurable amounts of IAA, but there was considerable variability in IAA production among the isolates after $72 \mathrm{~h}$ of growth (Table 2). The isolates $C$. vibroides, $P$. jessenii, and $S$. amiense produced similarly low levels of IAA that were $\sim 15 \times$ lower than that produced by $X$. melonis, and $65 \times$ lower compared to that produced by A. tumefaciens, which produced the highest concentrations of IAA of all strains tested.

Horizontal recruitment and vertical transmission of bacterial endophytes-Efficacy of seed surface sterilization-No microbial growth was detected from any of the surface-sterilized seeds used to streak the surface of all microbiological agar plates tested after incubating at $37^{\circ} \mathrm{C}$ for $\sim 2 \mathrm{wk}$ (data not shown).
In contrast, nonsurface-sterilized seeds generated growth on all microbiological agar plates tested after incubating at $37^{\circ} \mathrm{C}$ within $72 \mathrm{~h}$ (data not shown).

Bacterial community structure in rhizomes-Bacterial community fingerprints generated via denaturing gel gradient electrophoresis (DGGE) of partial 16S rRNA gene amplicons from plants in the microbial slurry amendments $\left(\mathrm{SN}_{2} \mathrm{FS}, \mathrm{ISBS}, \mathrm{SSS}\right)$ are depicted in Fig. 3. The DCA representation of the DGGEgenerated bacterial fingerprint from internal tissues of plants within each microbial slurry treatment indicated that fingerprints were more similar to each other than to those obtained from plants receiving other types of slurries, regardless of $\mathrm{N}$ treatment, with $53 \%$ of the total variance explained.

Nitrogenase activity in rhizomes-Plants grown from surfacesterilized seeds amended with sterile soil slurry (SSS) under $\mathrm{N}$-deprivation (-N) showed similar growth and rates of acetylene reduction to those amended with the Sorghum $\mathrm{N}_{2}$-fixing slurry $\left(\mathrm{SN}_{2} \mathrm{FS}\right)$, or with invaded-soil bacterial slurry (ISBS) (Fig. 4A, B respectively). Further, $\mathrm{N}$ fertilization increased plant growth similarly for all three treatments (see Fig. 4A; repeated measures ANOVA, $\left.F_{1,87}=311.73, P<0.0001\right)$. Microbial slurry amendment (SSS, $\mathrm{SN}_{2} \mathrm{FS}$, or ISBS) also had a significant effect on growth over time $\left(F_{2,87}=16.89, P<0.0001\right)$, but there was no significant interaction between $\mathrm{N}$ fertilization and microbial slurry amendment $\left(F_{2,87}=0.410, \mathrm{~ns}\right)$. Plants receiving $\mathrm{N}$ all grew taller than plants that did not receive N. At harvest (41 d), the mean height of plants receiving $\mathrm{N}$ was more than double that of those that did not receive N. Many of the plants receiving N (33\% combined total) tested positive for $\mathrm{AR}$, but the average rate of AR was almost $3 \times$ lower than AR activity in plants lacking $\mathrm{N}$ supplements. The majority (75\%) of plants deprived of $\mathrm{N}$ in all three microbial amendments (SSS, $\mathrm{SN}_{2} \mathrm{FS}$, and ISBS) tested positive for AR. Microbial slurry amendments did not affect AR rates (ANOVA, $F_{2,54}=0.127$, ns), while $\mathrm{N}$ had a significant effect on plant growth $\left(F_{1,54}=7.532, P<0.01\right)$. The interaction between microbial slurry amendment and $\mathrm{N}$ fertilization on $\mathrm{AR}$ rates $\left(F_{2,54}=0.499\right.$, ns $)$ was not significant.

Effects of antibiotics on endogenous endophyte activityExperimental inhibition of bacterial endophyte activity through the use of tetracycline was assessed in plants grown from surfacesterilized seeds. All plants deprived of $\mathrm{N}$ with active-state endophytes exhibited red leaf pigmentation, which, in sugar cane, indicates the presence of $\mathrm{N}_{2}$-fixing bacterial endophytes (Baldani et al., 1996). All plants were used to calculate growth rates (Fig. 4 and biomass allocation as root to shoot ratio (see below).

The growth of $S$. halepense was increased by active endophytes, regardless of $\mathrm{N}$-availability (Fig. 5A, B). In a repeated measures ANOVA for $S$. halepense height, there was a significant interaction $\left(F_{3,36}=4.428, P<0.05\right)$ between the effects of $\mathrm{N}$ fertilization and endophyte treatments (active vs. inactive). To explore this interaction, we conducted other repeated measures ANOVAs to separate the effects of endophyte status from $\mathrm{N}$ fertilization on the growth of $S$. halepense. In plants receiving $\mathrm{N}$, mean heights at the end of the study were $73.10 \pm 10.14 \mathrm{~cm}$ for endophyte inactive plants and $94.40 \pm 7.04 \mathrm{~cm}$ for endophyte active plants $\left(F_{1,18}=5.273, P<0.05\right)$. Growth of $S$. halepense under $\mathrm{N}$-deprivation was not significantly affected by endophyte activity status if the entire experimental period is integrated (repeated measures ANOVA, $F_{1,18}=2.881, P>0.1$ ), but at the end of the study there was a significant difference in 

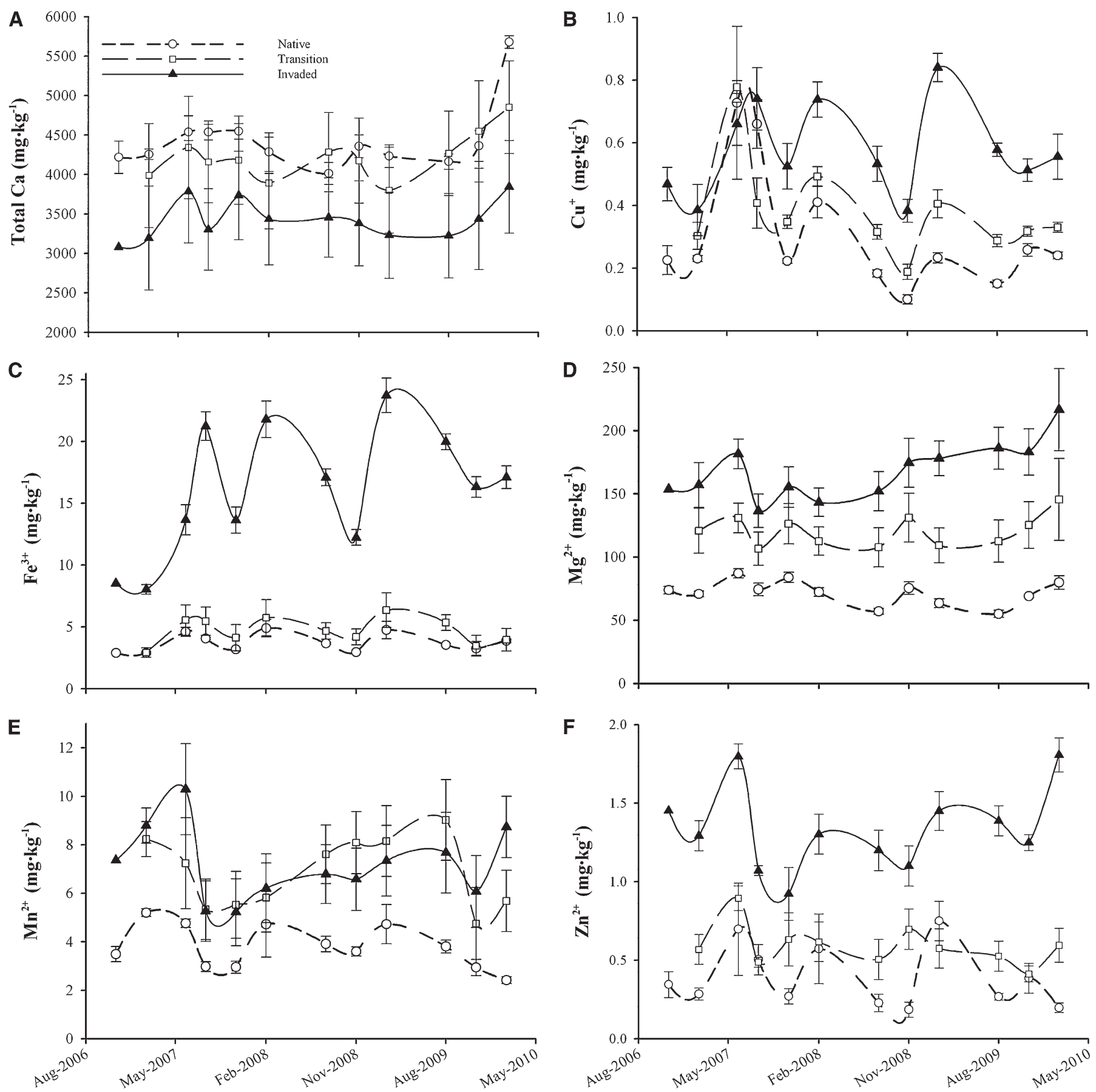

Time (month)

Time (month)

Fig. 1. Mean concentrations of soil macronutrients and trace metals per sample event from four replicate 1- $\mathrm{m}^{2}$ plots within each of native, transition, and invaded prairie $(n=4, N=12)$ sites at the FWNCR field site (see Site description and soil nutrient analyses in methods section). Soils were sampled quarterly November 2006-March 2010, with a total of 12 sampling points spanning 46 mo. Compared with native and transition plots, invaded soils contained the highest concentrations for metals throughout the study at all sampling intervals, with the exceptions of total Ca (A), which was lowest in invaded soils, and $\mathrm{Mn}^{2+}(\mathrm{E})$ which was not significantly different than in transition soils, but generally higher in transition and invaded soils than in native soils. Bars represent SE.

mean plant height $(4.90 \pm 1.37 \mathrm{~cm}$ for endophyte inactive and $7.60 \pm 1.46 \mathrm{~cm}$ for endophyte active) (Fig. 5). Not surprisingly, $\mathrm{N}$ fertilization had a highly significant effect on plant height for both endophyte treatments (endophyte active, $F_{1,18}=655.27$,
$P<0.0001$; endophyte inactive, $\left.F_{1,18}=105.76, P<0.0001\right)$. In an overall model comparing the effects of $\mathrm{N}$-fertilization and endophyte activity status, ANOVA on biomass at plant harvest (separated into root, shoot, and total biomass) showed significant 

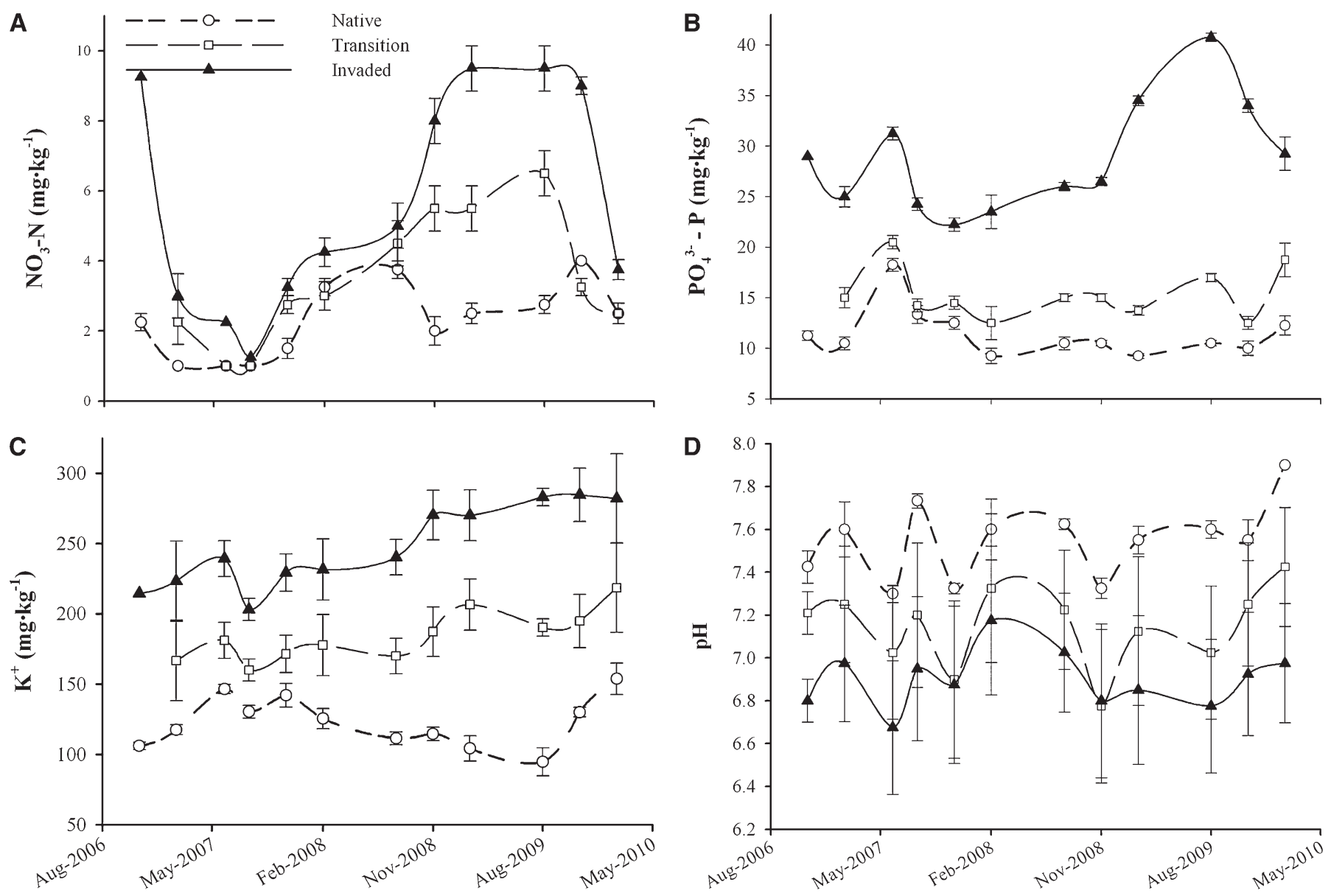

Time (month)

Time (month)

Fig. 2. Mean concentrations of soil macronutrients and $\mathrm{pH}$ from native, transition, and invaded prairie plots as described in Fig. 1. Invaded soils contained the highest concentrations of (A) $\mathrm{NO}_{3}{ }^{-}$, (B) $\mathrm{PO}_{4}{ }^{3-}$, and (C) $\mathrm{K}^{+}$and (D) lower $\mathrm{pH}$ compared with native soils at all sampling points throughout the study. Bars represent SE.

effects of endophyte treatment of all categories; $\mathrm{N}$ fertilization had highly significant effects on all biomass categories (Appendix 2). According to mean total biomass at harvest, $\mathrm{N}$ fertilized plants with active endophytes attained biomass that was more than $3 \times$ greater than those with inactive endophytes $(5.88 \pm$ $0.82 \mathrm{~g}$ and $1.86 \pm 0.36 \mathrm{~g}$, respectively); this effect was compounded under $\mathrm{N}$-deprivation yielding a 17 -fold increase in endophyte active compared to endophyte inactive plants $(0.255 \pm$ $0.002 \mathrm{~g}$ and $0.018 \pm 0.002 \mathrm{~g}$, respectively).
Root to shoot ratios for plants with active endophytes were similar, regardless of $\mathrm{N}$ fertilization status. Ratios for $+\mathrm{N}$ and $-\mathrm{N}$ treatments were $1.718 \pm 0.227$ and $1.658 \pm 0.269$ respectively; these ratios were at least double those for plants with inactivate endophytes. ANOVA revealed a significant effect of endophyte activity status (tetracycline treatment) but not $\mathrm{N}$ fertilization on root to shoot ratio $\left(F_{1,36}=36.28, P<0.0001 ; F_{1,36}=0.214\right.$, $P=$ ns respectively); this effect was driven by a significant decline (>5.5-fold) in belowground biomass (rhizomes) in endophyte

TABLE 2. Phosphate solubility measured as soluble reactive phosphate (SRP), indole-3-acetic acid (IAA) production, and classification of iron siderophore production by bacteria isolated from the rhizomes of Sorghum halepense.

\begin{tabular}{|c|c|c|c|c|c|}
\hline \multirow[b]{2}{*}{ Bacterium } & \multirow[b]{2}{*}{$\mathrm{SRP}(\mu \mathrm{mol} / \mathrm{L})$} & \multirow[b]{2}{*}{ IAA $\left(m g \cdot \mathrm{L}^{-1}\right)$} & \multicolumn{3}{|c|}{ Siderophore type } \\
\hline & & & O-CAS halo & Hydroxamate & Catechol \\
\hline Agrobacterium tumefaciens & 0 & $13.01 \pm 0.16^{*}$ & yellow-orange & + & - \\
\hline Pseudomonas jessenii (CIP 105274) & $13501 \pm 117 *$ & $0.22 \pm 0.07^{*}$ & yellow & + & - \\
\hline Sphingobium amiense (YT) & $6,904 \pm 681 *$ & $0.18 \pm 0.07 *$ & orange, pink & + & + \\
\hline Xanthomonas melonis (LMG8670) & $229 \pm 60 *$ & $2.69 \pm 0.40^{*}$ & orange & + & - \\
\hline
\end{tabular}

${ }^{a}$ Classifications based on criteria described in (Pérez-Miranda et al., 2007).

* Means differ significantly from zero. 


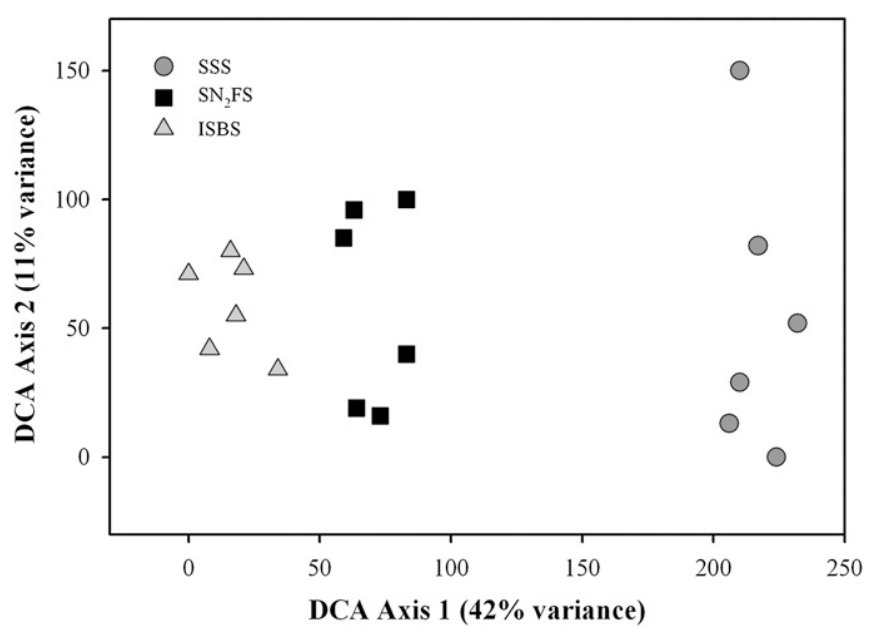

Fig. 3. Detrended correspondence analysis (DCA) of bacterial fingerprints from within Sorghum halepense rhizomes. Each symbol corresponds to an individual plant grown in aseptic conditions and exposed to one of three microbial slurry amendments: sterile soil slurry (SSS, $n=6$ ); invadedsoil bacteria slurry (ISBS, $n=6$ ); and Sorghum- $\mathrm{N}_{2}$-fixing bacteria slurry $\left(\mathrm{SN}_{2} \mathrm{FS}, n=6\right)$. DNA was extracted in duplicate from each rhizome and pooled, then each pooled sample was analyzed in triplicate by denaturing gel gradient electrophoresis (DGGE).

inactive compared to endophyte active plants $(0.33 \pm 0.12 \mathrm{~g}$ and $1.83 \pm 0.56 \mathrm{~g}$, respectively).

\section{DISCUSSION}

Invader impacts on soil biogeochemistry and link to in-vitro bacterial physiology_Sorghum halepense often grows in densely packed monocultures, which may reach densities of $>90$ ramets (individual members of a clonal plant) per square meter, with individual plants exceeding $2 \mathrm{~m}$ in height and producing $60-90 \mathrm{~m}$ of rhizomes per year (Holm et al., 1977; McWhorter, 1981). Rout and Chrzanowski (2009) found that soils invaded by $S$. halepense were characterized by elevated levels of $\mathrm{NO}_{3}{ }^{-} \mathrm{N}$, $\mathrm{PO}_{4}{ }^{3-}-\mathrm{P}, \mathrm{Fe}^{3+}$, and several other elements, compared with soils supporting native communities. Our current results support these prior findings; the soils displayed seasonal fluxes in the biogeochemical pools, but the consistently higher levels of all chemistries, with the exception of $\mathrm{Ca}$, and lower $\mathrm{pH}$ in invaded compared with transition and native soils were consistent throughout the study. This result suggests that the effects of $S$. halepense on biogeochemical cycles might be caused, at least in part, by the metabolic activity of the endophytic bacteria inhabiting the rhizomes of this invasive grass. Furthermore, our results demonstrate that endophytic bacteria have strong positive feedback on the growth and biomass allocation of S. halepense. These positive effects of endophytes are likely due to increased $\mathrm{N}$ supply through symbiotic $\mathrm{N}_{2}$ fixation and to enhanced supply of other key nutrients as indicated by bacterial effects on $\mathrm{Fe}, \mathrm{P}$, and IAA availability. The importance of these latter effects is emphasized by the slower growth of $S$. halepense when endophytes are inhibited (EI) even when experimentally supplied with large amounts of $\mathrm{N}$.

All five endophytic bacterial isolates demonstrated the capacity to mobilize insoluble $\mathrm{P}$ in vitro. Thus, in addition to fixing $\mathrm{N}_{2}$, these endophytes have the capacity to supply $S$. halepense with this additional critical nutrient. Increased $\mathrm{P}$ supply may be
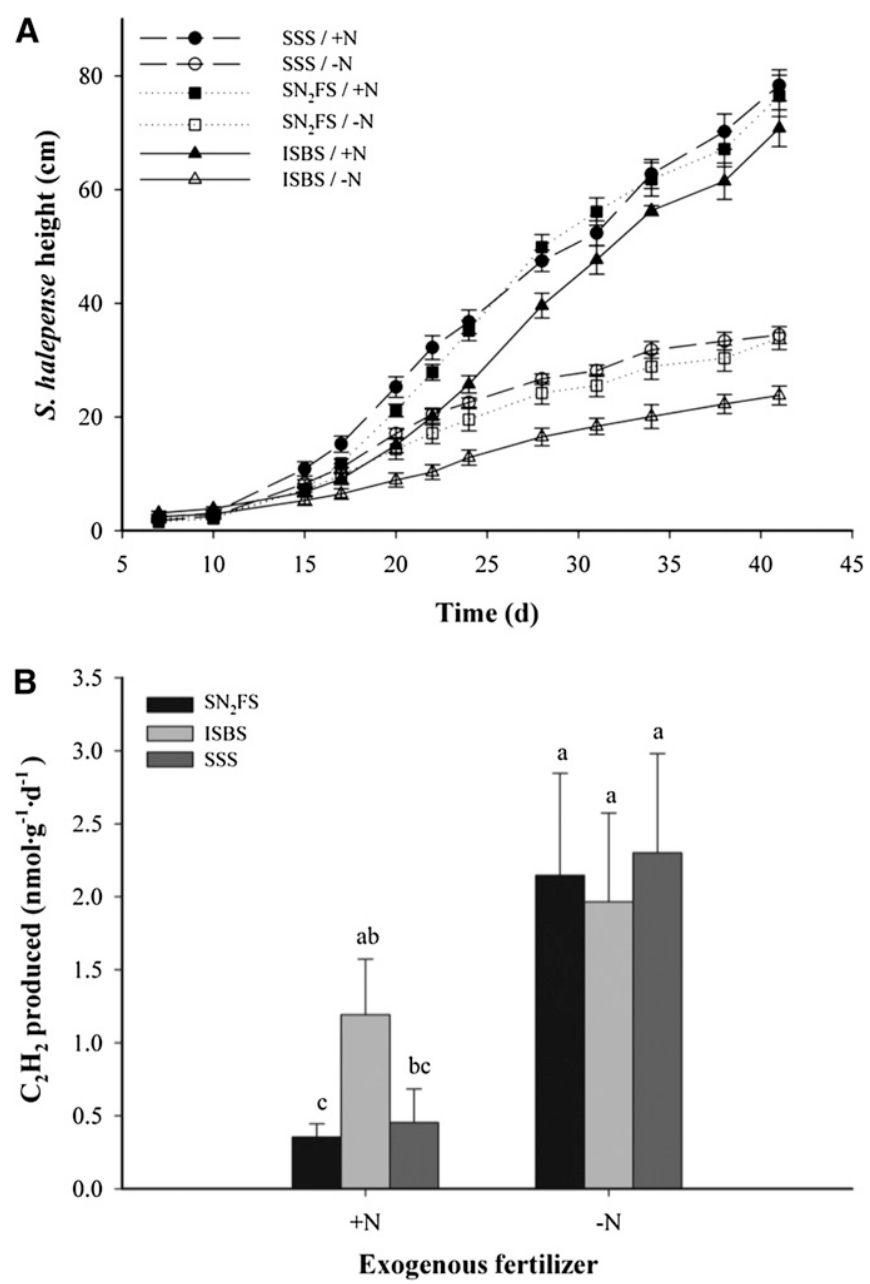

Fig. 4. Repeated measures of (A) growth (height) and (B) acetylene reduction (AR) rates for plants grown from seed under aseptic conditions and exposed to one of three microbial slurry amendments: sterile soil slurry (SSS); invaded-soil bacteria slurry (ISBS); and Sorghum- $\mathrm{N}_{2}$-fixing bacteria slurry $\left(\mathrm{SN}_{2} \mathrm{FS}\right)$. Each of these slurry treatments received two complete fertilizer regimes, only differing in the levels of $\mathrm{N}\left(+\mathrm{N}=1000 \mathrm{mg} \mathrm{NO}{ }^{-}-\mathrm{N} \cdot \mathrm{L}^{-1}\right.$, $-\mathrm{N}=0 \mathrm{mg} \mathrm{NO}{ }^{-}-\mathrm{N} \cdot \mathrm{L}^{-1}$ ); where combined $n=15, N=90$ in (A) and $n=12$, $N=72$ in (B). Letters denote that means differed significantly; bars represent SE.

important for a plant with high $\mathrm{N}$ acquisition because as $\mathrm{N}$ supply increases, P deficiency can limit plant growth (Stevenson and Cole, 1999). This scenario is supported for S. halepense; our results showed decreased total $\mathrm{Ca}$ and increased $\mathrm{PO}_{4}{ }^{3-}$ in S. halepense-invaded soils. Results from many terrestrial ecosystems suggest that symbiotic $\mathrm{N}_{2}$-fixing plants have advantages for $\mathrm{P}$ acquisition from soils, and there are many potential mechanisms for this effect (reviewed in Houlton et al., 2008). Clearly, some endophytes mobilize $\mathrm{P}$ in excess of their needs (P. jessenii, S. amiense, and X. melonis), while others might only mobilize enough insoluble $\mathrm{P}$ to support their own growth.

Iron chelation is another common metabolic feature among bacteria. Pools of $\mathrm{Fe}^{3+}$ were high in S. halepense-invaded soils compared with native and transition soils, and we found that endophytic bacteria have the potential to contribute to this effect. All five isolates produced Fe siderophores in vitro, potentially liberating insoluble Fe into bioavailable forms in acidic soils, which occurred with $S$. halepense invasion. In fact, $\mathrm{Fe}^{3+}$ concentrations 

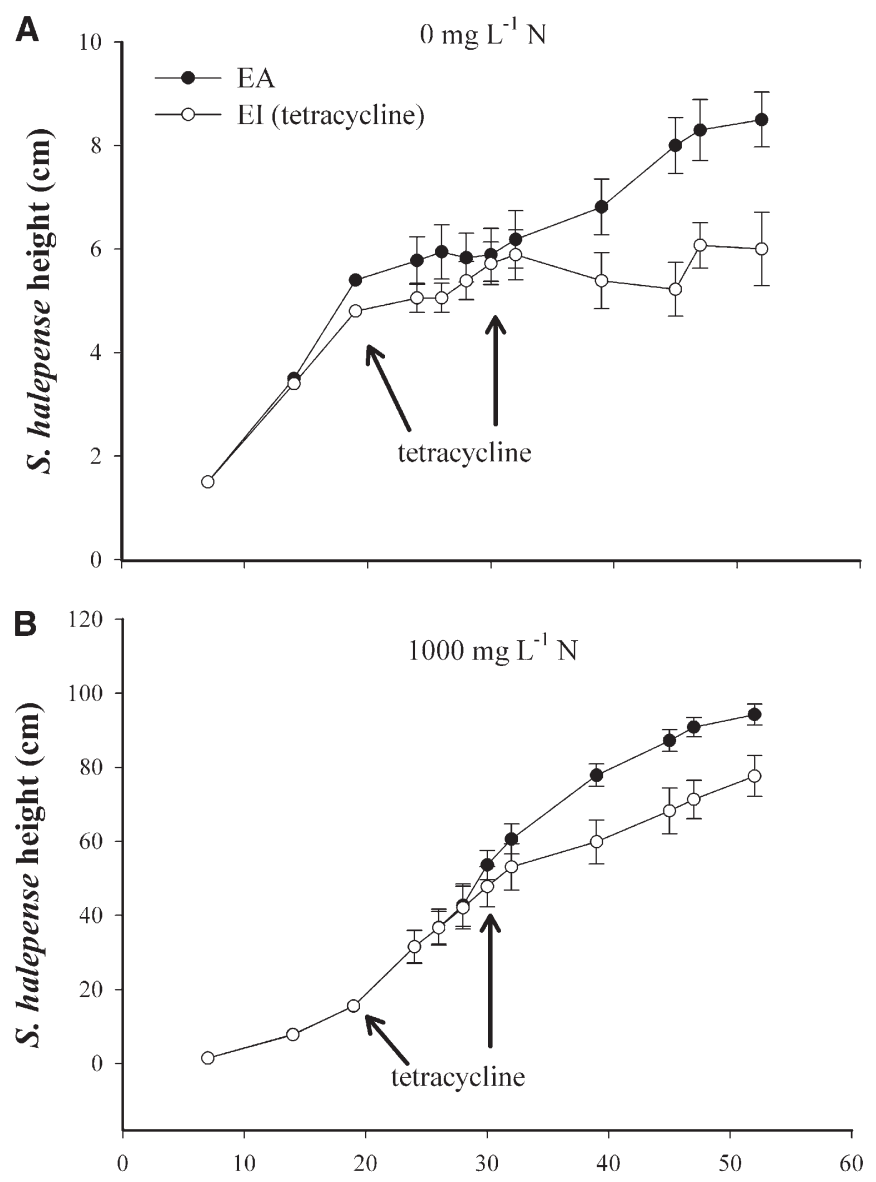

Time (d)

Fig. 5. Repeated measures of growth (height) of Sorghum halepense grown in sterile $\mathrm{RAH}$ medium (A) devoid of $\mathrm{N}\left(0 \mathrm{mg} \mathrm{NO} \mathrm{N}_{3}-\mathrm{N} \cdot \mathrm{L}^{-1}\right)$ or (B) supplemented with high $\mathrm{N}\left(1000 \mathrm{mg} \mathrm{NO} \mathrm{N}_{3}-\mathrm{N} \cdot \mathrm{L}^{-1}\right)$. Surface-sterilized seedlings were aseptically transferred into receptacles at $7 \mathrm{~d}$ after which growth was repeatedly measured as the height of green tissue above the surface of the medium. Tetracycline $\left(12.5 \mathrm{mg} \cdot \mathrm{mL}^{-1}\right.$; EI, open symbols) or sterile water (EA, solid symbols) were injected into the substrates of each replicate in both $\mathrm{N}$-amendments $(n=9, N=36)$ on two occasions $(17,32 \mathrm{~d})$ indicated by the arrows on the graph. Bars represent SE. Note the change in scale between the two panels.

in invaded soils reached levels that are toxic to many crops (Stevenson and Cole, 1999) and might also have negative effects on native species and deter establishment of competitive species in invaded areas. How $S$. halepense tolerates these high $\mathrm{Fe}^{3+}$ concentrations is currently unknown. Our findings further emphasize the importance of the bacterial community in invaded soils on the positive feedback observed in the field on $S$. halepense density (Rout and Chrzanowski, 2009; Rout et al., 2013) and suggest a number of mechanisms that might explain the altered soil biogeochemical parameters observed for invaded soils in this study.

Evidence of horizontal recruitment and vertical transmission of bacterial endophytes-Other evidence from the present study suggests that plant-microbe associations are influenced through horizontal recruitment into rhizomes. The significant overall effect of microbial slurry amendments on repeated measures of growth and the DCA analysis of DGGE-generated bacterial fingerprints from $S$. halepense rhizomes indicated that this plant could recruit a variety of bacterial partners from the physical matrix in which it grows. The DCA analysis of DGGE fingerprints indicates that the bacterial profiles in the plant tissues ultimately reflect the bacterial consortium present in the growth matrix of the root zone since clustering of replicates indicates similarities of the DGGE-generated fingerprint. Our understanding of the extent of this capability and the identities of potential bacterial recruits (e.g., symbionts, plant-growth-promoting bacteria (PGPB), pathogens, competitors) are limited due to the nature of our experimental design. DGGE indicates community-level differences and alone it does not yield identities of community members.

The type of soil microbial amendments had a significant effect on the growth of $S$. halepense, but the primary determinant of plant height was $\mathrm{N}$ supply from our fertilization treatments. However, the survival and growth of $S$. halepense deprived of $\mathrm{N}$ (SSS/-N treatments) showed that these plants were acquiring $\mathrm{N}$ from a source other than introduced $\mathrm{N}$, strongly suggesting that $\mathrm{N}_{2}$ fixation by endophytic bacteria that were transferred vertically via seeds provide $S$. halepense with this nutrient in $\mathrm{N}$-limited environments. This was confirmed by the positive results for nitrogenase activity in these same plants, which were grown aseptically from surface-sterilized seeds. Additionally, AR rates were approximately equal for all plants growing under $\mathrm{N}$-deprivation; and this finding was substantiated by the lack of a significant effect of soil microbial amendments. From these findings and our prior endophyte isolation and nitrogenase production efforts (Rout and Chrzanowski, 2009), we conclude that $S$. halepense seeds contain $\mathrm{N}_{2}$-fixing bacteria, and that these are vertically transmitted from generation to generation.

Impacts of endogenous endophytes on growth and link to in-vitro bacterial IAA production-Our results show that bacterial endophytes significantly increase the growth of $S$. halepense and alter resource allocation in ways that may further contribute to rapid growth. Most importantly, these effects were eliminated when bacterial endophytes were inhibited with tetracycline. These results are not an artifact of the tetracycline itself, and the importance of $S$. halepense endophytes is illustrated by a key finding regarding $\mathrm{N}$ fertilization. The growth (height and biomass) of $S$. halepense plants grown in both $\mathrm{N}$ fertilization treatments with active endophytes was greater than that of plants with inhibited endophytes, indicating that $S$. halepense relies on bacterial partners for maximum growth even when exogenous $\mathrm{N}$ is abundantly available. Furthermore, the belowground biomass of $S$. halepense was significantly reduced when endophyte activity was restricted. Since the decline in root to shoot ratio was similar for endophyte-inhibited plants (EI), irrespective of $\mathrm{N}$ treatment, endophytic bacteria might somehow be essential for maximal rhizome production (belowground biomass), and this resource allocation is not related to bioavailable $\mathrm{N}$ in soil. In light of previous research that estimated rhizome growth rates of 60-90 m per year for an individual plant (McWhorter, 1981) and rhizomatous advances by $S$. halepense in this same field site documented at $\sim 0.45 \mathrm{~m}$ per year (Rout et al., 2013), our findings suggest that bacterial endophytes play a substantial role in resource allocation toward rhizomes and invasion persistence for this invasive grass. We do not currently know the mechanism(s) by which bacterial endophytes increase rhizome growth, but the capacity of bacteria to produce the plant-growthpromoting substance IAA may be an important factor. 
IAA is synthesized by approximately $80 \%$ of bacterial taxa in plant rhizospheres (Loper and Schroth, 1986). Secreted at low levels, IAA promotes root growth (Patten and Glick, 1996; Glick, 1995), but high levels, typical of plant pathogenic bacteria, inhibit plant growth and cause developmental perturbations (Sarwar and Kremer, 1995). Thus, IAA promotes plant growth under some circumstances, yet is inhibitory under others. Each of the five bacterial isolates was capable of producing IAA; $P$. jessenii, $S$. amiense, and $C$. vibroides produced IAA at levels known to induce root growth among various plant species; while $X$. melonis and A. tumefaciens produced IAA at levels typical of plant pathogens. It is not possible to determine whether the in vitro rates of IAA production are typical of what occurs in situ, but it seems likely that bacterial production of IAA contributes to the aboveground growth and rhizome biomass of $S$. halepense observed in this study. Bacterial and other biotic and abiotic environmental factors might regulate plant hormonal pathways, including IAA and ethylene production, which represent integrated pathways leading to plant growth and senescence (Hardoim et al., 2008). The bacterial contribution to hormone signaling pathways in $S$. halepense remains to be determined.

Conceptual model of bacterial endophytes role in enhanced invasive plant competition-On the basis of these collective findings, we propose a revision to the conceptual model proposed by Rout and Chrzanowski (2009) referred to as microbially enhanced competitive ability. The original model proposes that rhizosphere $\mathrm{N}_{2}$ fixed by endophytic bacteria in rhizomes is converted into $\mathrm{NH}_{4}{ }^{+}$and shuttled into plant biomass and dhurrin (constitutive N-containing defense compound) synthesis. This revised model (Fig. 6) shows both direct and indirect actions of bacterial endophytes potentially contributing to higher soil $\mathrm{PO}_{4}{ }^{3-}$ and $\mathrm{Fe}^{3+}$, and lower total $\mathrm{Ca}$ levels, in invaded soils. Our finding of in vitro production of IAA suggests an additional feedback loop, creating more rhizomatous growth that can support additional endophyte loads, likely exacerbating these ecological impacts. This study indicates that a diverse array of microbially mediated mechanisms appears to increase the prolific growth of S. halepense and contributes to the substantive perturbations to soil biogeochemical cycles co-occurring with invasions. We suggest that the physiological activities of bacterial endophytes in this (and possibly other) invasive plant species might play a larger and more direct role than previously perceived.

Conclusions-The most striking feature of this study is that a diverse array of microbially mediated mechanisms appears to not only increase the prolific growth of $S$. halepense, but also contribute to the substantive perturbations to soil biogeochemical cycles co-occurring with invasion. We suggest that the physiological activities of bacterial endophytes in this invasive plant may play a larger and more direct role than previously perceived in these biogeochemical perturbations. For example, it is known that plant invasions, on average, cause an increase in net primary productivity as well as increased concentrations of soil nutrients (Liao et al., 2008; Rout and Callaway, 2009, 2012). Thus, it is important to ask whether bacterial endophytes, as exemplified by these five isolates from $S$. halepense, have similar effects in other invasive plant species. If so, it becomes crucial to compare how invasive plants affect microbially mediated soil processes in native and nonnative ranges.

Presumably, these multiple plant-microbe interactions of both vertically transmitted and horizontally acquired endophytes are all simultaneously active in this single invasive plant system.

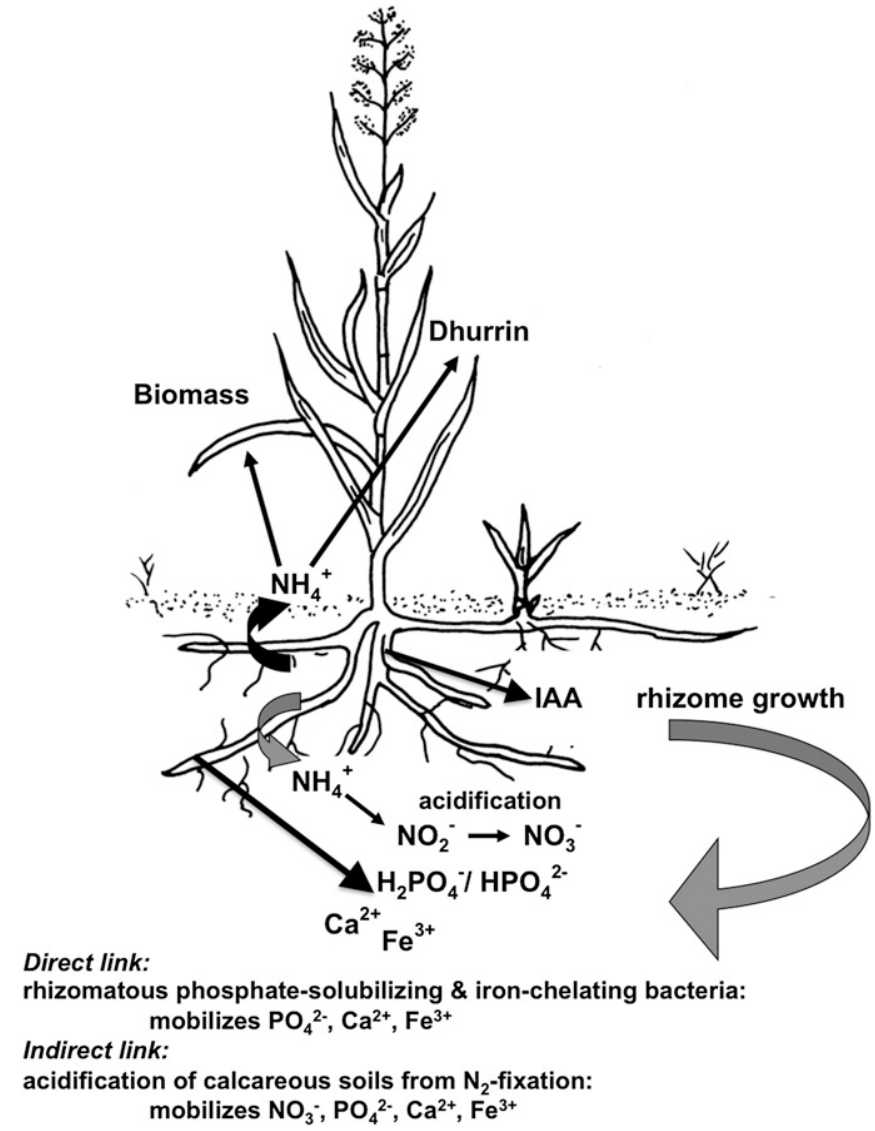

Fig. 6. Conceptual model of microbial processes occurring in the rhizosphere of Sorghum halepense (revised from that presented in Rout and Chrzanowski, 2009). In this scenario, rhizosphere $\mathrm{N}_{2}$ is fixed by endophytic $\mathrm{N}_{2}$-fixing bacteria within rhizomes. $\mathrm{NH}_{4}{ }^{+}$is shuttled into plant biomass and dhurrin (plant $\mathrm{N}$-containing defense compound in $\mathrm{S}$. halepense leaves) synthesis. Some $\mathrm{NH}_{4}{ }^{+}$is lost to the rhizosphere and converted rapidly into $\mathrm{NO}_{3}{ }^{-}$, the preferred form of external $\mathrm{N}$ for $S$. halepense. Oxidation of $\mathrm{NH}_{4}{ }^{+}$and $\mathrm{NO}_{2}{ }^{-}$acidifies soils, potentially promoting dissolution of hydroxyapatite and thereby indirectly resulting in increased available $\mathrm{PO}_{4}{ }^{3-}, \mathrm{Ca}^{2+}$, and $\mathrm{Fe}^{3+}$ for plant uptake and growth. In addition, endophytic bacteria previously isolated from $S$. halepense rhizomes contribute directly to these latter processes (this study) by solubilizing $\mathrm{PO}_{4}{ }^{3-}$ and chelating $\mathrm{Fe}^{3+}$. The in vitro bacterial production of plant growth hormone IAA suggests an additional feedback loop in this system, creating more rhizomatous growth, supporting additional bacterial endophyte loads, and potentially exacerbating the above direct and indirect effects.

To our knowledge, these results represent the most diverse repertoire of microbially enhanced invasive traits described for a single plant. It seems reasonable to assume that other microbially mediated processes that occur in invasive plant tissues and rhizospheres remain to be discovered. Thus, the roles and importance of indigenous or exotic bacterial endophytes in plant invasion systems represent an intriguing, yet largely underexplored aspect of exotic plant invasion studies.

\section{LITERATURE CITED}

Allison, S. D., And P. M. Vitousek. 2004. Rapid nutrient cycling in leaf litter from invasive plants in Hawai' i. Oecologia 141: 612-619.

Atlas, R. M. 2004. Handbook of microbiological media. CRC Press, London, UK. 
Baldani, J. I., B. Рot, G. Kirchhof, E. Flasen, V. L. D. Baldani, F. L. Olivares, B. Hoste, ET AL. 1996. Emended description of Herbaspirillum; inclusion of [Pseudomonas] rubrisubalbicans, a mild plant pathogen, as Herbaspirillum rubrisubalbicans comb. nov.; and classification of a group of clinical isolates (EF Group 1) as Herbaspirillum species 3. International Journal of Systematic Bacteriology 46: 802-810.

Ehrenfeld, J. G. 2003. Effects of exotic plant invasions on soil nutrient cycling processes. Ecosystems 6: 503-523.

Feris, K. P., P. W. Ramsey, C. F. Frazar, M. C. Rillig, J. E. Gannon, and W. E. Holben. 2003. Structure and seasonal dynamics of hyporheic zone microbial communities in free-stone rivers of the western United States. FEMS Microbiology Ecology 46: 200-215.

Fiske, C. H., AND Y. Subbarow. 1925. The colorimetric determination of phosphorus. Journal of Biological Chemistry 66: 375-400.

Glick, B. R. 1995. The enhancement of plant growth by free-living bacteria. Canadian Journal of Microbiology 41: 109-117.

GoRDON, D. R. 1998. Effects of invasive, non-indigenous plant species on ecosystem processes: Lessons from Florida. Ecological Applications 8: 975-989.

Grube, M., M. Cardinale, J. V. de Castro Jr., H. Miller, and G. Berg. 2009. Species-specific structural and functional diversity of bacterial communities in lichen symbioses. ISME Journal 3: 1105-1115.

Hardoim, P. R., L. S. van Overbeek, and J. D. van Elsas. 2008. Properties of bacterial endophytes and their proposed role in plant growth. Trends in Microbiology 16: 463-471.

Holm, L. G., P. Donald, J. V. Pancho, and J. P. Herberger. 1977. The world's worst weeds: Distribution and biology. University Press of Hawaii, Honolulu, Hawaii, USA.

Houlton, B. Z., Y. Wang, P. M. Vitousek, and C. B. Field. 2008. A unifying framework for dinitrogen fixation in the terrestrial biosphere. Nature 454: 327-331.

Inderitt, H. Evans, C. Crocoli, D. Bajpai, R. Kaur, Y.-L. Feng, C. Silva, ET AL. 2011. Volatile chemicals from leaf litter are associated with invasiveness of a Neotropical weed in Asia. Ecology 92: 316-324.

Liao, C., R. Peng, Y. Luo, X. Zhou, X. Wu, C. Fang, J. Chen, and B. Li. 2008. Altered ecosystem carbon and nitrogen cycles by plant invasion: A meta-analysis. New Phytologist 177: 706-714.

LOPER, J. E., AND M. N. SCHROTH. 1986. Influence of bacterial source of indole-3-acetic acid on root elongation of sugar beet. Phytopathology 76: $386-389$

Maron, J. L., AND M. Marler. 2008. Field-based competitive impacts between invaders and natives at varying resource supply. Journal of Ecology 96: 1187-1197.

McWhorTer, C. G. 1981. Johnson grass as a weed. USDA Farm Bulletin 1537: 3-19.
NAUTIYAL, C. S. 1999. An efficient microbiological growth medium for screening phosphate solubilizing microorganisms. FEMS Microbiology Letters 170: 265-270.

Patten, C. L., And B. R. Glick. 1996. Bacterial biosynthesis of indole-3acetic acid. Canadian Journal of Microbiology 42: 207-220.

Pérez-Miranda, S., N. Cabirol, R. George-Téllez, L. S. Zamudio-Rivera, AND F. J. FernándeZ. 2007. O-CAS, a fast and universal method for siderophore detection. Journal of Microbiological Methods 70: 127-131.

Rout, M. E., and R. M. Callaway. 2009. An invasive plant paradox. Science 324: 734-735. doi:10.1126/science.1173651

Rout, M. E., and R. M. Callaway. 2012. Interactions between exotic invasive plants and soil microbes in the rhizosphere suggest that 'everything is not everywhere'. Annals of Botany 110: 213-222.

Rout, M. E., and T. H. Chrzanowski. 2009. The invasive Sorghum halepense harbors endophytic $\mathrm{N}_{2}$-fixing bacteria and alters soil biogeochemistry. Plant and Soil 315: 163-172.

Rout, M. E., T. H. Chrzanowski, W. K. Smith, and L. Gough. 2013. Ecological Impacts of the invasive grass Sorghum halepense on native tallgrass prairie. Biological Invasions 15: 327-339. doi:10.1007/ s10530-012-0289-7

Reasoner, D. J., J. C. Blannon, and E. E. Geldreich. 1979. Rapid sevenhour fecal coliform test. Applied and Environmental Microbiology 38: 229-236.

Rodríguez, H., and R. Fraga. 1999. Phosphate solubilizing bacteria and their role in plant growth promotion. Biotechnology Advances 17: 319-339.

Sarwar, M., and R. J. Kremer. 1995. Enhanced suppression of plant growth through production of L-tryptophan-derived compounds by deleterious rhizobacteria. Plant and Soil 172: 261-269.

Schwyn, B., AND J. B. NeILANDS. 1987. Universal chemical assay for the detection and determination of siderophores. Analytical Biochemistry 160: 47-56.

Stevenson, F. J., And M. A. Cole. 1999. Cycles of soil: Carbon, nitrogen phosphorus, sulfur, and micronutrinets, 2nd ed. John Wiley, New York, New York, USA.

Thorpe, A. S., V. Archer, and T. H. DeLuca. 2006. The invasive forb, Centaurea maculosa, increases available phosphorus availability in Montana grasslands. Journal of Applied Soil Ecology 32: 118-122.

VILÀ, M., AND J. WeINER. 2004. Are invasive plant species better competitors than native plant species? - Evidence from pair-wise experiments. Oikos 105: 229-238.

Vitousek, P. M., C. M. D'antonio, L. L. Loope, M. Rejmanek, and R. WestBROOKs. 1997. Introduced species: A significant component of human-caused global change. New Zealand Journal of Ecology 21: 1-16. 
APPENDIX 1. Statistics for repeated measures multivariate between-subjects ANOVA for soil biogeochemistries from native, transition and invaded soils.

\begin{tabular}{|c|c|c|c|c|c|c|}
\hline Source & Dependent variable & Type III sum of squares & $\mathrm{df}$ & Mean square & $F$ & $P$ \\
\hline \multirow[t]{10}{*}{ Corrected model } & $\mathrm{NO}_{3}$ & 780.797 & 34 & 22.965 & 29.948 & $<0.0001$ \\
\hline & $\mathrm{PO}_{4}$ & 9440.920 & 34 & 277.674 & 17.322 & $<0.0001$ \\
\hline & $\mathrm{K}$ & 449833.116 & 34 & 13230.386 & 10.959 & $<0.0001$ \\
\hline & $\mathrm{Ca}$ & 36049745.567 & 34 & 1060286.634 & 1.870 & 0.008 \\
\hline & $\mathrm{Mg}$ & 252740.880 & 34 & 7433.555 & 11.67 & $<0.0001$ \\
\hline & $\mathrm{Fe}$ & 5788.725 & 34 & 170.257 & 4.388 & $<0.0001$ \\
\hline & $\mathrm{Zn}$ & 27.841 & 34 & 0.819 & 9.977 & $<0.0001$ \\
\hline & $\mathrm{Mn}$ & 557.755 & 34 & 16.405 & 4.487 & $<0.0001$ \\
\hline & $\mathrm{Cu}$ & 10.241 & 34 & 0.301 & 9.807 & $<0.0001$ \\
\hline & $\mathrm{pH}$ & 12.594 & 34 & 0.370 & 2.308 & 0.001 \\
\hline \multirow[t]{10}{*}{ Intercept } & $\mathrm{NO}_{3}$ & 1823.944 & 1 & 1823.944 & 2378.560 & $<0.0001$ \\
\hline & $\mathrm{PO}_{4}$ & 46862.942 & 1 & 46862.942 & 2923.371 & $<0.0001$ \\
\hline & $\mathrm{K}$ & 4612674.936 & 1 & 4612674.936 & 3820.890 & $<0.0001$ \\
\hline & $\mathrm{Ca}$ & $2.230 \mathrm{E} 9$ & 1 & $2.230 \mathrm{E} 9$ & 3933.638 & $<0.0001$ \\
\hline & $\mathrm{Mg}$ & 1958161.312 & 1 & 1958161.312 & 3074.980 & $<0.0001$ \\
\hline & $\mathrm{Fe}$ & 9506.325 & 1 & 9506.325 & 245.018 & $<0.0001$ \\
\hline & $\mathrm{Zn}$ & 81.229 & 1 & 81.229 & 989.718 & $<0.0001$ \\
\hline & $\mathrm{Mn}$ & 4669.752 & 1 & 4669.752 & 1277.263 & $<0.0001$ \\
\hline & $\mathrm{Cu}$ & 28.664 & 1 & 28.664 & 933.240 & $<0.0001$ \\
\hline & $\mathrm{pH}$ & 7143.762 & 1 & 7143.762 & 44514.757 & $<0.0001$ \\
\hline \multirow{10}{*}{$\begin{array}{l}\text { Community (native, } \\
\text { transition, invaded) }\end{array}$} & $\mathrm{NO}_{3}$ & 203.684 & 2 & 101.842 & 132.810 & $<0.0001$ \\
\hline & $\mathrm{PO}_{4}$ & 7058.671 & 2 & 3529.335 & 220.164 & $<0.0001$ \\
\hline & $\mathrm{K}$ & 331996.794 & 2 & 165998.397 & 137.504 & $<0.0001$ \\
\hline & $\mathrm{Ca}$ & 22004241.542 & 2 & 11002120.771 & 19.405 & $<0.0001$ \\
\hline & $\mathrm{Mg}$ & 196936.434 & 2 & 98468.217 & 154.629 & $<0.0001$ \\
\hline & $\mathrm{Fe}$ & 4593.636 & 2 & 2296.818 & 59.199 & $<0.0001$ \\
\hline & $\mathrm{Zn}$ & 19.888 & 2 & 9.944 & 121.162 & $<0.0001$ \\
\hline & $\mathrm{Mn}$ & 272.522 & 2 & 136.261 & 37.270 & $<0.0001$ \\
\hline & $\mathrm{Cu}$ & 0.928 & 2 & 0.464 & 15.104 & $<0.0001$ \\
\hline & $\mathrm{pH}$ & 8.372 & 2 & 4.186 & 26.084 & $<0.0001$ \\
\hline \multirow{10}{*}{ Time (month) } & $\mathrm{NO}_{3}$ & 397.973 & 11 & 36.179 & 47.181 & $<0.0001$ \\
\hline & $\mathrm{PO}_{4}$ & 809.134 & 11 & 73.558 & 4.589 & $<0.0001$ \\
\hline & $\mathrm{K}^{+}$ & 43972.922 & 11 & 3997.538 & 3.311 & 0.001 \\
\hline & $\mathrm{Ca}$ & 10069900.191 & 11 & 915445.472 & 1.615 & 0.105 \\
\hline & $\mathrm{Mg}$ & 20390.768 & 11 & 1853.706 & 2.911 & 0.002 \\
\hline & $\mathrm{Fe}$ & 521.569 & 11 & 47.415 & 1.222 & 0.282 \\
\hline & $\mathrm{Zn}$ & 3.504 & 11 & 0.319 & 3.881 & $<0.0001$ \\
\hline & $\mathrm{Mn}$ & 158.208 & 11 & 14.383 & 3.934 & $<0.0001$ \\
\hline & $\mathrm{Cu}$ & 6.628 & 11 & 0.603 & 19.618 & $<0.0001$ \\
\hline & $\mathrm{pH}$ & 2.710 & 11 & 0.246 & 1.535 & 0.130 \\
\hline \multirow[t]{10}{*}{ Community $\times$ time } & $\mathrm{NO}_{3}$ & 163.818 & 21 & 7.801 & 10.173 & $<0.0001$ \\
\hline & $\mathrm{PO}_{4}$ & 1107.442 & 21 & 52.735 & 3.290 & $<0.0001$ \\
\hline & K & 38713.394 & 21 & 1843.495 & 1.527 & 0.084 \\
\hline & $\mathrm{Ca}$ & 3661031.045 & 21 & 174334.812 & 0.307 & 0.998 \\
\hline & $\mathrm{Mg}$ & 20542.231 & 21 & 978.201 & 1.536 & 0.081 \\
\hline & $\mathrm{Fe}$ & 439.498 & 21 & 20.928 & 0.539 & 0.947 \\
\hline & $\mathrm{Zn}$ & 2.843 & 21 & 0.135 & 1.650 & 0.052 \\
\hline & $\mathrm{Mn}$ & 98.839 & 21 & 4.707 & 1.287 & 0.201 \\
\hline & $\mathrm{Cu}$ & 2.529 & 21 & 0.120 & 3.921 & $<0.0001$ \\
\hline & $\mathrm{pH}$ & 0.989 & 21 & 0.047 & 0.293 & 0.999 \\
\hline
\end{tabular}


APPENDIX 2. Statistics for repeated measures multivariate between-subjects ANOVA for Sorghum halelpense biomass at harvest from experiments conducted in sterile RAH medium.

\begin{tabular}{|c|c|c|c|c|c|c|}
\hline Source & Dependent variable & Type III sum of squares & df & Mean square & $F$ & $P$ \\
\hline \multirow[t]{3}{*}{ Corrected model } & Root mass & 73.760 & 3 & 24.587 & 29.091 & $<0.0001$ \\
\hline & Shoot mass & 28.364 & 3 & 9.455 & 37.292 & $<0.0001$ \\
\hline & Total mass & 186.484 & 3 & 62.161 & 39.643 & $<0.0001$ \\
\hline \multirow[t]{3}{*}{ Intercept } & Root mass & 39.520 & 1 & 39.520 & 49.760 & $<0.0001$ \\
\hline & Shoot mass & 25.362 & 1 & 25.362 & 100.034 & $<0.0001$ \\
\hline & Total mass & 128.201 & 1 & 128.201 & 81.759 & $<0.0001$ \\
\hline \multirow[t]{3}{*}{ Endophyte status (EA, EI) } & Root mass & 19.124 & 1 & 19.124 & 22.627 & $<0.0001$ \\
\hline & Shoot mass & 2.193 & 1 & 2.193 & 8.651 & 0.006 \\
\hline & Total mass & 34.269 & 1 & 34.269 & 21.855 & $<0.0001$ \\
\hline \multirow[t]{3}{*}{ Fertilizer $(+\mathrm{N},-\mathrm{N})$} & Root mass & 38.701 & 1 & 38.701 & 45.791 & $<0.0001$ \\
\hline & Shoot mass & 24.755 & 1 & 24.755 & 97.638 & $<0.0001$ \\
\hline & Total mass & 125.360 & 1 & 125.360 & 79.947 & $<0.0001$ \\
\hline \multirow[t]{3}{*}{ Endophyte $\times$ fertilizer } & Root mass & 18.931 & 1 & 18.931 & 22.399 & $<0.0001$ \\
\hline & Shoot mass & 2.193 & 1 & 2.193 & 8.649 & 0.006 \\
\hline & Total mass & 34.009 & 1 & 34.009 & 21.689 & $<0.0001$ \\
\hline
\end{tabular}

